\title{
Partitioning of Sorbitol and Sucrose Catabolism within Peach Fruit
}

\author{
Riccardo Lo Bianco and Mark Rieger \\ Department of Horticulture, University of Georgia, Athens, GA 30602
}

\begin{abstract}
AdDitional InDEX words. acid invertase, Prunus persica, sink, sorbitol dehydrogenase, sucrose, sucrose synthase
\end{abstract}
\begin{abstract}
The peach [Prunus persica (L.) Batsch (Peach Group)] fruit is a sink organ comprised of different types of tissue, which undergoes three distinct developmental stages during the growth season. The objective of this study was to characterize the activity and partitioning of sorbitol and sucrose catabolism within 'Encore' peach fruit to determine whether the two forms of translocated carbon play different roles in the various fruit tissues and/or stages of development. Sorbitol catabolic activity was defined as the sum of NAD-dependent sorbitol dehydrogenase (SDH) and sorbitol oxidase (SOX) activities, whereas sucrose catabolic activity was defined as the sum of sucrose synthase (SS), soluble acid invertase (AI), and neutral invertase (NI) activities. Partitioning of sorbitol and sucrose catabolism in each tissue was calculated as percentage of total sorbitol or sucrose catabolic activity in the entire fruit. At cell division, sorbitol catabolic activity was similar in the endocarp and mesocarp, but lower in the seed. However, sorbitol catabolism was mostly partitioned into the mesocarp, due to its large size compared to that of other tissues. SDH was more active in the mesocarp, while SOX was more active in the endocarp. Sucrose catabolism was most active and partitioned mainly into the endocarp. At endocarp hardening, both sorbitol and sucrose catabolic activities were highest in the seed, but despite this, sucrose catabolism was partitioned mostly in the mesocarp. At cell expansion, sorbitol and sucrose catabolic activities were still higher in the seed only when expressed on a weight basis and similar in mesocarp and seed when expressed on a protein basis. Both sorbitol and sucrose catabolism were partitioned mostly into the mesocarp. Sorbitol and sucrose contents were generally higher in the tissues that exhibited lower catabolic activities. All carbohydrates were always partitioned mostly into the mesocarp. Our results show that, at the cell division and endocarp hardening stages, sorbitol and sucrose catabolism are partitioned differently in the fruit and that SDH activity may play an important role in mesocarp cell division and final fruit size determination.
\end{abstract}

The peach [Prunus persica (L.) Batsch (Peach Group)] and other stone fruit are characterized by three stages of growth: an early period of rapid cell division, an intermediate stage of relatively slow growth, and a final swell due to cell expansion. In mid- and late-maturing cultivars, this growth pattern is represented by a double-sigmoid curve (Westwood, 1993), although early-maturing cultivars do not show an intermediate or endocarp hardening stage. Already in the cell division stage, the fruit tissues start differentiating into the mesocarp (flesh), endocarp (pit), and seed. In this first stage, the mesocarp and endocarp are very active and account for nearly all the fruit growth. During the second stage, the mesocarp undergoes a relatively quiescent period and the endocarp lignifies. The seed, on the other hand, undergoes an active stage of growth due to compositional changes and accumulation of storage compounds. The final period of fruit growth is characterized by cell expansion and carbohydrate accumulation in the mesocarp, and maturation in the seed. Thus, the fruit sink is comprised of separate parts, which act themselves as sinks, experiencing changes in activity and demand for photosynthate during the season.

Sorbitol and sucrose are both synthesized in mature leaves of peach trees and are present at ratios of about $4: 1$, respectively (Escobar-Gutièrrez and Gaudillère, 1994). This ratio decreases to 2:1 in the translocating tissues (leaf petiole, stem bark, and fruit peduncle) and down to 1:4 and 1:50 late in the season in the fruit mesocarp and seed, respectively (R. Lo Bianco, unpublished data). In the fruit mesocarp, sucrose accumulates more than sorbitol late in the season (Lo Bianco et al., 1999a), suggesting

Received for publication 8 Mar. 2001. Accepted for publication 29 Sept. 2001. The cost of publishing this paper was defrayed in part by the payment of page charges. Under postal regulations, this paper therefore must be hereby marked advertisement solely to indicate this fact. that the two forms of translocated carbon may play different roles depending on the growth stage and/or tissue type.

In species that produce and translocate sorbitol, NAD-dependent sorbitol dehydrogenase (SDH, EC 1.1.1.14) represents the main enzyme of sorbitol catabolism in sinks. It catalyzes the oxidation of sorbitol to fructose and is active in apple [Malus sylvestris (L.) Mill. var. domestica (Borkh.) Mansf.] fruit (Yamaki and Ishikawa, 1986; Yamaguchi et al., 1996), in young apple leaves (Loesher et al., 1982), in peach shoot apices, elongating shoot internodes, and root apices (Lo Bianco et al., 1999b), and in shoot apices of wild Prunus L. sp. (Lo Bianco et al., 1998). Sorbitol oxidase (SOX), which converts sorbitol to glucose (Yamaki, 1980), seems to play a minor role in apple compared to SDH (Yamaki and Ishikawa, 1986), but is often detected in peach tissues (Lo Bianco et al., 1999b; Moriguchi et al., 1990). Previous studies on sorbitol catabolism in fruit have considered the activity of both enzymes only in the mesocarp (Lo Bianco et al., 1999a; Moriguchi et al., 1990). However, recently, high levels of SDH activity have been detected in peach seeds (Lo Bianco, unpublished data). Thus, further characterization of sorbitol catabolism in fruit should consider both enzymes, as well as tissues other than mesocarp that use sorbitol.

Among the sucrose metabolizing enzymes, soluble acid invertase (AI, EC 3.2.1.26) is active in peach fruit mesocarp during cell division and cell expansion stages and follows the fruit growth pattern (Lo Bianco et al., 1999a). Toward maturation, when peach fruit have nearly reached their final size, accumulation of sucrose in the mesocarp seems to be explained in part by a decrease in AI activity (Lo Bianco et al., 1999a; Vizzotto et al., 1996). Also, an increase in sucrose phosphate synthase and sucrose synthase (SS, EC 2.4.1.13) activity assayed in the synthetic direction (Hubbard et al., 1991) or only SS activity (Moriguchi et al., 1990) may be associated to sucrose accumulation in peach fruit. However, as 
with sorbitol, there is no information on sucrose metabolism in peach seeds and the role that sucrose enzymes may play in fruit development and sink strength.

Warren Wilson (1972) proposed that sink strength is the product of sink size and sink activity, or sink weight and relative growth rate. In this model, the size represents the physical constraint, whereas the activity reflects the physiological constraint on the sink's assimilate import (Ho, 1988). Also, the activity of sucrose (Sung et al., 1989) and sorbitol (Lo Bianco et al., 1999b) catabolic enzymes has been associated to growth rate in various species. Thus, it should be possible to estimate sink strength in peach fruit by measuring the activity of sorbitol and sucrose enzymes per unit weight (activity) and the weight of the sink (size) (Farrar, 1993). Consideration of sorbitol and sucrose enzyme activities from all fruit tissues (not only the mesocarp) and the sink size factor should therefore provide a more complete picture of the role that the two carbon sources play in sink strength and development of the peach fruit.

The purpose of this study was to characterize sorbitol and sucrose catabolism in the entire peach fruit. Preliminary data suggested that the two forms of translocated carbon were associated with different tissues within the fruit, and with different stages of fruit development (Lo Bianco, unpublished data), and further characterization was performed to evaluate a unique function for sorbitol in polyol-forming plants.

\section{Materials and Methods}

Plant materials. Fruit were collected from April to July 2001 from 8-year-old 'Encore' peach trees once in each of the three growth stages, at $\approx 50,85$, and $130 \mathrm{~d}$ after bloom. Trees were propagated on 'Lovell' rootstock, spaced $2 \times 7 \mathrm{~m}$ apart, and located at the Horticulture Research Farm near Athens, Ga. Samples (six fruit per date) were harvested in the morning and quickly transported from the field to the laboratory. Two separate sets of samples were collected, one used for determination of enzyme activities, and the second for later determination of carbohydrate content. For the enzyme assays, half of each fruit was extracted immediately for SDH, the other half stored at $-20^{\circ}$ for subsequent determination of AI, neutral invertase (NI, EC 3.2.1.27), SOX, and SS activities. During cell division stage, enzymes were extracted from mesocarp, endocarp, and seed separately. After lignification of the endocarp, enzymes were extracted only from mesocarp and seed, since the endocarp tissue could not be extracted.

ENZYMe EXTRACTION AND ASSAYS. For all enzymes, the tissue:buffer ratio $(\mathrm{w} / \mathrm{v})$ in the extractions varied from 1:3 to 1:4 for fruit mesocarp and endocarp, and from 1:5 to 1:10 for seeds. SDH, SS, SOX, and the soluble fraction of AI and NI were extracted and assayed as described in Lo Bianco et al. (1999a) with few modifications. SDH was extracted in $0.2 \mathrm{M}$ Tris- $\mathrm{HCl}$ buffer ( $\mathrm{pH} 9$ at $25^{\circ} \mathrm{C}$ ) containing $8 \%$ (v/v) glycerol, and $20 \mathrm{~mm}$ 2-mercaptoethanol. SS, AI, NI, and SOX were extracted in $0.2 \mathrm{M}$ Hepes/ $\mathrm{NaOH}$ buffer (pH 7.5 at $25{ }^{\circ} \mathrm{C}$ ) containing $10 \mathrm{~mm}$ dithiothreitol (DTT), 3 mm Mg-acetate, and 8\% (v/v) glycerol. Tween $20(0.1 \%$, v/v) and polyvinylpolypyrrolidone (PVPP; $1 \%$, $\mathrm{w} / \mathrm{v})$ were added in all extractions during grinding. The homogenates were centrifuged at $3000 \mathrm{~g}_{\mathrm{n}}$ for $15 \mathrm{~min}$ and the supernatants desalted with Sephadex G-25 (medium) columns.

$\mathrm{SDH}$ was assayed by measuring the continuous change in optical density (OD) at $340 \mathrm{~nm}$ at $25^{\circ} \mathrm{C}$ on a Spectronic Genesys 5 spectrophotometer (Spectronic Instruments, Inc., Rochester, N.Y.) over a 5-min period using $0.2 \mathrm{~mL}$ of desalted extract, $0.1 \mathrm{M}$ Tris- $\mathrm{HCl}$ buffer ( $\mathrm{pH} 9.5$ at $25^{\circ} \mathrm{C}$ ), and $1 \mathrm{~mm} \mathrm{NAD}^{+}$. The reaction was started by adding $400 \mathrm{~mm}$ sorbitol ( $1 \mathrm{~mL}$ final volume). SS was assayed by measuring the continuous change in OD at 340 $\mathrm{nm}$ at $25^{\circ} \mathrm{C}$ on the Spectronic Genesys 5 spectrophotometer using $0.2 \mathrm{~mL}$ of desalted extract, $100 \mathrm{~mm}$ sucrose, $0.5 \mathrm{~mm}$ UDP, and 1 mM PPi as substrates, and phosphoglucomutase (1 unit) and Leuconostoc glucose-6-phosphate dehydrogenase (1 unit) as coupling enzymes. AI and NI were assayed with $25 \mathrm{~mm}$ sucrose at $\mathrm{pH} 5$ and $100 \mathrm{~mm}$ sucrose at $\mathrm{pH} 7$, respectively, whereas SOX was assayed with $400 \mathrm{~mm}$ sorbitol at $\mathrm{pH}$ 4. After $30 \mathrm{~min}$ of incubation at $25^{\circ} \mathrm{C}$, the reaction was stopped by boiling for 10 min. The AI and SOX reaction mixtures were neutralized before boiling. The glucose formed then was measured using hexokinase (1 unit) and Leuconostoc glucose-6-phosphate dehydrogenase ( 1 unit). In all enzyme assays, activities were proportional to the amount of extract and time. All enzymes were assayed under saturating conditions.

Enzyme activities were presented only on a weight basis [nanomoles of NADH produced per minute per gram of fresh weight $(\mathrm{FW})$ ], but also calculated on a protein basis (nanomoles of NADH produced per minute per milligram of protein) to reveal possible differences in activities relative to tissue composition and development. When significant, differences between activities on a weight basis and protein basis are indicated in the text. The sum of the activities on a weight basis of all sorbitol or sucrose enzymes was used to calculate sorbitol (SorCA) or sucrose (SucCA) catabolic activity. Partitioning of sorbitol and sucrose catabolism was expressed as a percentage and calculated as follows: (SorCA or SucCA $\times$ tissue weight $\times 100$ )/Total sorbitol or sucrose catabolic activity per fruit. Protein content was determined by the method of Bradford (1976).

Table 1. Sorbitol dehydrogenase (SDH), sorbitol oxidase (SOX), and sorbitol catabolic (SorCA) activities in the various tissues of the peach fruit at the three growth stages.

\begin{tabular}{|c|c|c|c|c|}
\hline \multirow{2}{*}{$\begin{array}{l}\text { Growth } \\
\text { stage }\end{array}$} & \multirow[b]{2}{*}{ Tissue } & $\mathrm{SDH}$ & SOX & SorCA \\
\hline & & \multicolumn{3}{|c|}{$\left(\mathrm{nmol} \cdot \mathrm{min}^{-1} \cdot \mathrm{g}^{-1} \mathrm{FW}\right)$} \\
\hline \multirow[t]{3}{*}{ Cell division } & Mesocarp & $22.0 \mathrm{a}^{\mathrm{z}}$ & $15.7 \mathrm{~b}$ & $37.7 \mathrm{a}$ \\
\hline & Endocarp & $1.1 \mathrm{~b}$ & $38.6 \mathrm{a}$ & $39.8 \mathrm{a}$ \\
\hline & Seed & $4.0 \mathrm{~b}$ & $0 \mathrm{c}$ & $4.0 \mathrm{~b}$ \\
\hline \multirow[t]{2}{*}{ Endocarp hardening } & Mesocarp & $1.9 \mathrm{~b}$ & $0 \mathrm{a}$ & $1.9 \mathrm{~b}$ \\
\hline & Seed & $187.3 \mathrm{a}$ & $0 \mathrm{a}$ & $187.3 \mathrm{a}$ \\
\hline \multirow[t]{2}{*}{ Cell expansion } & Mesocarp & $2.6 \mathrm{~b}$ & $5.0 \mathrm{a}$ & $7.6 \mathrm{~b}$ \\
\hline & Seed & $108.2 \mathrm{a}$ & $14.1 \mathrm{a}$ & $122.3 \mathrm{a}$ \\
\hline
\end{tabular}

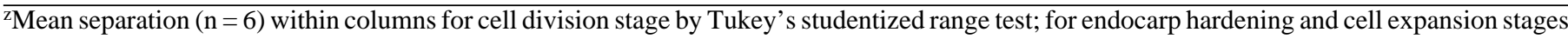
by $t$ test (unpaired) at $P \leq 0.05$. 
SORBITOL AND NONSTRUCTURAL CARBOHYDRATES. About 0.1 to $0.12 \mathrm{~g}$ of mesocarp, endocarp, or seed tissue was ground in a mortar and pestle with $2 \mathrm{~mL}$ of $80 \%$ (v/v) methanol containing $0.22 \mathrm{mg}$ of phenyl- $\beta$-D-glucopyranose as an internal standard. After homogenization, samples were centrifuged for $10 \mathrm{~min}$ at $2000 g_{\mathrm{n}}$ and $1 \mathrm{~mL}$ of the supernatant was stored at $4{ }^{\circ} \mathrm{C}$ for soluble carbohydrate and sorbitol determination. The pellet was washed with $80 \%$ methanol and centrifuged twice. The supernatant was discarded, $1 \mathrm{~mL}$ of deionized water was added, and tubes were placed in boiling water for $1 \mathrm{~h}$ to gelatinize the starch. One milliliter of deionized water, $1 \mathrm{~mL}$ of acetate buffer ( $\mathrm{pH} 4.8$ ), and $0.1 \mathrm{~mL}$ of amyloglucosidase enzyme solution ( 7 units) was added and tubes were placed in a water bath at $55^{\circ} \mathrm{C}$ for $24 \mathrm{~h}$. Tubes were then centrifuged and $1 \mathrm{~mL}$ of the supernatant was stored at $-20^{\circ} \mathrm{C}$ for starch determination.

Samples were prepared for sugar quantification as described in Lo Bianco et al. (2000). Briefly, $0.1 \mathrm{~mL}$ of extract was dried in 200- $\mu \mathrm{L}$ gas chromatograph vials at $40^{\circ} \mathrm{C}$ and $0.07 \mathrm{~mL}$ of $\mathrm{N}$, obis(trimethylsilyl)trifluoroacetamide (BSTFA) and dimethylformamide (DMF) $(1: 1, \mathrm{v} / \mathrm{v})$ was added. Vials were then capped, vortexed, and ultrasonicated for $15 \mathrm{~min}$. Derivatization was completed by heating vials at $75^{\circ} \mathrm{C}$ for 1.5 h. Soluble carbohydrates and sorbitol were quantified with a gas chromatograph (model 5940; Hewlett Packard, Avondale, Pa.), using a DB5 column (30 m length, 0.3 $\mathrm{mm}$ i.d., $0.25 \mathrm{~mm}$ film thickness).

Starch content was determined by measuring enzymatically the amount of glucose formed (modified from Chaplin 1994). Hexokinase (1 unit) and Leuconostoc glucose6-phosphate dehydrogenase (1 unit) were used in the presence of ATP and NAD and the total change in OD was measured spectrophotometrically. Carbohydrate data were expressed in milligrams per gram of $\mathrm{FW}$ of the considered tissue or as a percentage in a particular tissue of the total in the entire fruit.

STatistical analysis. Sigma Stat procedures (SPSS, Inc., Chicago, Ill.) were used to determine differences among mean values in various tissues. Analysis of variance was performed to test differences among the three tissues at the cell division stage and among growth stages for mesocarp and seed. Tukey's studentized range test was used to separate means. For endocarp hardening and cell expansion stages, a $t$ test (unpaired) was used to test differences between mesocarp and seed.

\section{Results}

ENZYMe aCtIVITIES AND PARTITIONING AMONG TISSUES. At the cell division stage, SorCA was similar in the endocarp and mesocarp, but lower in the seed (Table 1). However, total sorbitol catabolic activity was mostly partitioned into the mesocarp (Fig. 1). The mesocarp:pit:seed FW ratio was about 15:7:1. Between sorbitol enzymes, SDH was more active in the mesocarp, while SOX was more active in the endocarp (Table 1). SucCA was higher in the endocarp than in the mesocarp and seed (Table 2), and total activity of sucrose was also partitioned mostly into the endocarp (Fig. 1). SS activity was highest in the seed, and lowest in the mesocarp, while AI was predominantly active in the endocarp (Table 2 ). NI activity was not detected in seeds and very variable in mesocarp and endocarp (Table 2). In all cases, activities on a FW and protein basis followed the same patterns. In general, sorbitol was mostly catabolized in the mesocarp, whereas sucrose was catabolized in the endocarp at the cell division stage.

At endocarp hardening, SorCA and SucCA were higher in the seed than in the mesocarp (Tables 1 and 2). However, sorbitol catabolism was mostly partitioned into the seed, whereas sucrose catabolism was partitioned into the mesocarp (Fig. 1). The

Fig. 1. Partitioning of total sorbitol and sucrose catabolic activities among the various tissues of the peach fruit at the three growth stages. Area of pie charts is proportional to total activity per fruit.

\section{Sorbitol Catabolism}

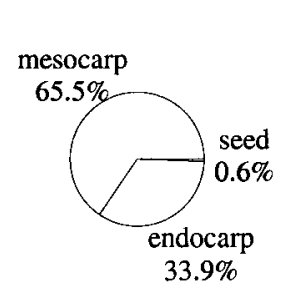

Total Fruit Activity $=268 \mathrm{nmol} \cdot \mathrm{min}^{-1}$

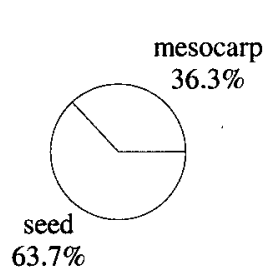

Total Fruit Activity $=273 \mathrm{nmol} \cdot \mathrm{min}^{-1}$
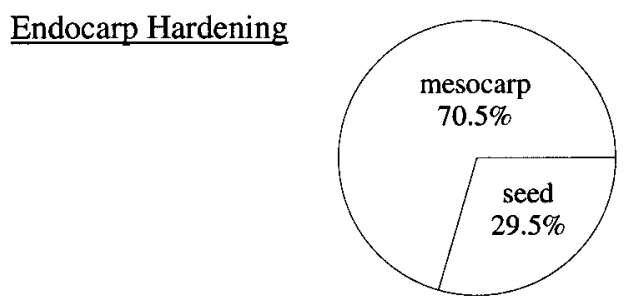

Total Fruit Activity $=549 \mathrm{nmol} \cdot \mathrm{min}^{-1}$

\section{Sucrose Catabolism}

\section{$\underline{\text { Cell Division }}$}

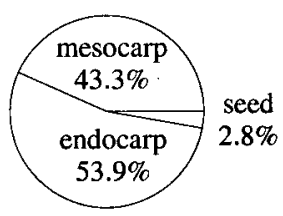

Total Fruit Activity $=1120 \mathrm{nmol} \cdot \mathrm{min}^{-1}$
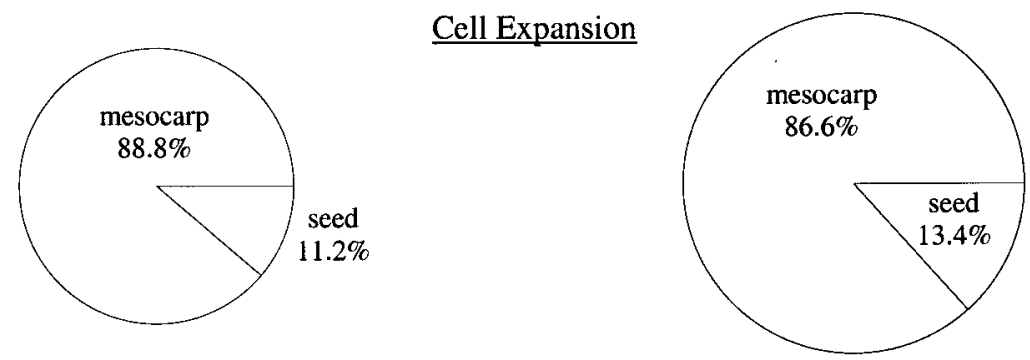

Total Fruit Activity $=1116 \mathrm{nmol} \cdot \mathrm{min}^{-1}$

Total Fruit Activity $=1701 \mathrm{nmol} \cdot \mathrm{min}^{-1}$ 
Table 2. Sucrose synthase (SS), acid invertase (AI), neutral invertase (NI), and sucrose catabolic (SucCA) activities in the various tissues of the peach fruit at the three growth stages.

\begin{tabular}{|c|c|c|c|c|c|}
\hline \multirow{2}{*}{$\begin{array}{l}\text { Growth } \\
\text { stage }\end{array}$} & \multirow[b]{2}{*}{ Tissue } & SS & AI & NI & SucCA \\
\hline & & \multicolumn{4}{|c|}{$\left(\mathrm{nmol} \cdot \mathrm{min}^{-1} \cdot \mathrm{g}^{-1} \mathrm{FW}\right)$} \\
\hline \multirow[t]{3}{*}{ Cell division } & Mesocarp & $4.6 b^{z}$ & $30.7 \mathrm{~b}$ & $1.5 \mathrm{a}$ & $36.8 \mathrm{~b}$ \\
\hline & Endocarp & $17.9 \mathrm{ab}$ & $108.4 \mathrm{a}$ & $8.6 \mathrm{a}$ & $134.8 \mathrm{a}$ \\
\hline & Seed & $24.9 \mathrm{a}$ & $14.2 \mathrm{~b}$ & $0 \mathrm{a}$ & $39.1 \mathrm{~b}$ \\
\hline \multirow[t]{2}{*}{ Endocarp hardening } & Mesocarp & $5.2 \mathrm{~b}$ & $9.1 \mathrm{~b}$ & $0 \mathrm{a}$ & $14.3 \mathrm{~b}$ \\
\hline & Seed & $252.6 \mathrm{a}$ & $86.5 \mathrm{a}$ & $13.7 \mathrm{a}$ & $352.8 \mathrm{a}$ \\
\hline \multirow[t]{2}{*}{ Cell expansion } & Mesocarp & $0.4 \mathrm{~b}$ & $4.6 \mathrm{~b}$ & $7.3 \mathrm{a}$ & $12.3 \mathrm{~b}$ \\
\hline & Seed & $165.1 \mathrm{a}$ & $44.3 \mathrm{a}$ & $9.1 \mathrm{a}$ & $218.5 \mathrm{a}$ \\
\hline
\end{tabular}

${ }^{\mathrm{z}}$ Mean separation $(\mathrm{n}=6)$ within columns for cell division stage by Tukey's studentized range test; for endocarp hardening and cell expansion stages by $t$ test (unpaired) at $P \leq 0.05$.

mesocarp:seed FW ratio was about 60:1. SOX activity was not detected in either tissue and all other enzymes were generally more active in the seed than in the mesocarp (Tables 1 and 2). When expressed on a protein basis, only AI activity was similar in mesocarp and seed $(P \leq 0.05)$. Sorbitol was predominantly catabolized in the seed, whereas sucrose was cleaved mainly in the mesocarp at this stage.

At the cell expansion stage, SorCA and SucCA were still more active in the seed (Tables 1 and 2). However, if expressed on a protein basis, sorbitol and sucrose catabolic activities were similar in mesocarp and seed $(P \leq 0.05)$ due to the relatively high protein content in the seed (data not presented). Total catabolic activities of both sorbitol and sucrose were mostly partitioned into the mesocarp (Fig. 1). The mesocarp:seed FW ratio was about 144:1; thus the lower activity in the mesocarp is more than compensated for by the mesocarp weight. SDH, SS, and AI activities were higher in the seed than in the mesocarp, while SOX and NI were equally active in mesocarp and seed (Tables 1 and 2). However, if expressed on a protein basis, only SS activity remained higher in the seed than in the mesocarp $(P \leq 0.05)$. No difference between spatial partitioning of sorbitol and sucrose catabolism was revealed at this stage.

ENZYME ACTIVITIES COMPARED AMONG GROWTH STAGES. Mesocarp SDH, SOX, and AI were most active at the cell division stage (Tables 1 and 2; $P \leq 0.05$ ), whereas mesocarp SS decreased significantly only at the cell expansion stage (Table 2; $P \leq 0.05$ ). In the seed, all enzyme activities except SOX were highest at endocarp hardening (Tables 1 and $2 ; P \leq 0.05$ ).

CARbohydrate CONTENTS AND PARTITIONING AMONG Tissues. In the cell division stage, sorbitol and fructose contents were highest in the endocarp, followed by the mesocarp, and lowest in the seed (Table 3 ). However, their total contents were mostly partitioned into the mesocarp (Fig. 2). Sucrose content was highest in the mesocarp and lowest in the endocarp (Table 3), and over $83 \%$ was partitioned into the mesocarp (Fig. 2). Glucose content was highest in the endocarp and similar in mesocarp and seed (Table 3), but almost entirely and evenly partitioned into mesocarp and endocarp (Fig. 2). Starch content was about the same in the three tissues, and therefore partitioned according to tissue FW (Fig. 2). Seed carbohydrates represented $<5 \%$ of total in all cases. At endocarp hardening and cell expansion stages, sorbitol, sucrose, fructose, and glucose contents were higher in the mesocarp, while starch content was higher in the seed (Table 3). However, all carbohydrates were mostly partitioned into the mesocarp in both growth stages (Figs. 3 and 4) with the exception of starch that was not detected in the mesocarp at cell expansion (Fig. 4).

CARBOHYDRATE CONTENTS COMPARED AMONG GROWTH STAGES. In the mesocarp, sorbitol, sucrose, and glucose accumulated gradually from cell division to cell expansion, whereas fructose and starch decreased significantly at cell expansion (Table 3; $P \leq$ $0.05)$. In the seed, only sucrose showed the same gradual increase over time, whereas sorbitol remained constant, and glucose was lowest at cell division and equally higher in the other two stages (Table 3; $P \leq 0.05$ ). Fructose decreased gradually with time, whereas starch peaked at endocarp hardening (Table 3; $P \leq 0.05$ ).

\section{Discussion}

During fruit development, sink strength is affected by both changes in size of individual organs and their activity (Warren Wilson, 1972). Early in the season, SorCA is similar in peach mesocarp and endocarp (Table 1). However, partitioning of total activities indicates that the mesocarp represents the strongest sink for sorbitol, due to its larger size rather than relative activity. Also, the two enzymes of sorbitol breakdown are mostly active in different tissues, and specifically SOX is more active in the

Table 3. Sorbitol, sucrose, fructose, glucose, and starch contents in the various tissues of the peach fruit at the three growth stages.

\begin{tabular}{|c|c|c|c|c|c|c|}
\hline $\begin{array}{l}\text { Growth } \\
\text { stage }\end{array}$ & Tissue & Sorbitol & Sucrose & Fructose & Glucose & Starch \\
\hline \multirow[t]{2}{*}{ Cell division } & Mesocarp & $0.5 \mathrm{~b}^{\mathrm{z}}$ & $1.5 \mathrm{a}$ & $12.9 \mathrm{~b}$ & $3.5 \mathrm{~b}$ & $1.2 \mathrm{a}$ \\
\hline & Seed & $0.3 \mathrm{c}$ & $1.1 \mathrm{ab}$ & $1.8 \mathrm{c}$ & $1.9 \mathrm{~b}$ & $1.1 \mathrm{a}$ \\
\hline \multirow[t]{2}{*}{ Endocarp hardening } & Mesocarp & $5.2 \mathrm{a}$ & $17.7 \mathrm{a}$ & $14.8 \mathrm{a}$ & $8.1 \mathrm{a}$ & $1.3 \mathrm{~b}$ \\
\hline & Seed & $0.4 \mathrm{~b}$ & $10.9 \mathrm{~b}$ & $1.4 \mathrm{~b}$ & $4.0 \mathrm{~b}$ & $2.1 \mathrm{a}$ \\
\hline
\end{tabular}

${ }^{\mathrm{z}}$ Mean separation $(\mathrm{n}=6)$ within columns for cell division stage by Tukey's studentized range test; for endocarp hardening and cell expansion stages by $t$ test (unpaired) at $P \leq 0.05$. 
endocarp and SDH in the mesocarp at cell division. The total number of cells in the fruit mesocarp is a critical determinant of potential fruit size, thus SDH may be important in determination of final fruit size. Alternatively, sucrose catabolism seems to be more active and mostly partitioned into the endocarp at cell division (Table 2, Fig. 1). Thus, the endocarp is the strongest sink for sucrose, and SucCA, particularly AI activity, plays the predominant role in endocarp sink strength. The higher sucrose content and partitioning into the mesocarp also agrees with lower SucCA in mesocarp vs. endocarp at cell division (Table 3, Fig. 2). Sorbitol, fructose, glucose, and starch were also partitioned according to the relative size of each tissue.

At endocarp hardening, SDH is the only enzyme of sorbitol catabolism detected and is concentrated mainly in the seed (Table 1), where important compositional changes occur during this stage (mainly protein accumulation; Lo Bianco, unpublished data). Despite its small size compared to the mesocarp, the seed

Fig. 2. Partitioning of total fructose, glucose, sorbitol, sucrose, and starch contents among the various tissues of the peach fruit at the cell division stage. Area of pie charts is proportional to total content per fruit.

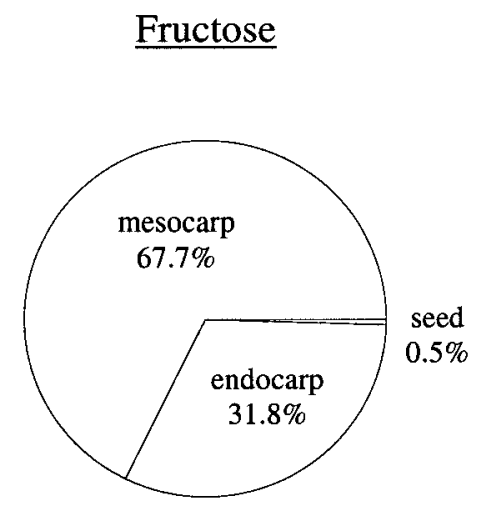

Total Fruit Content $=122.9 \mathrm{mg}$

\section{$\underline{\text { Glucose }}$}

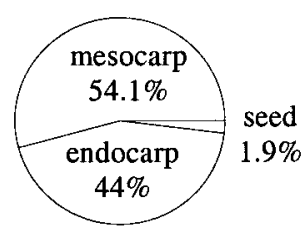

Total Fruit Content $=41.7 \mathrm{mg}$ is the strongest sink for sorbitol at endocarp hardening and SDH activity plays the predominant role in sink strength. Also, higher content and greater partitioning of sorbitol into the mesocarp than the seed agree with the finding that sorbitol catabolism is more active in the seed at this time (Table 3, Fig. 3). Sucrose catabolism is also more active in the seed during endocarp hardening, but mostly partitioned into the mesocarp. Therefore, unlike sorbitol, mesocarp size represents the major component of sink strength for sucrose at this stage.

In the final cell expansion stage, the FW of the mesocarp is several times greater than that of the seed, and even though SorCA and SucCA are higher in the seed (Tables 1 and 2), the mesocarp contains most of the sorbitol and sucrose catabolic activities (Fig. 1). In other words, the mesocarp represents a stronger sink for sorbitol and sucrose during cell expansion because of the size component rather than the activity. The seed at this stage is still an active sink undergoing tissue maturation (Lo Bianco, unpublished data), characterized by synthesis of lipids at high respiratory cost (Amthor, 1994). This is confirmed by the relatively high activity of nearly all enzymes (Tables 1 and 2) and the relatively low carbohydrate content in the seed (Table 3). However, the contribution of the seed to total fruit sink strength is relatively low due to its small size compared to that of the mesocarp.

The cell division process, typical of the early stage of peach fruit growth, is associated with relatively low sucrose:hexose ratios, while cell differentiation and reserve accumulation seem to be triggered by relatively high sucrose contents, a pattern also observed in seed development (Sturm and Tang, 1999; Weber et al., 1997). The observed decrease in soluble AI activity in the fruit mesocarp from cell division to cell expansion stage may therefore play a role in sucrose accumulation and developmental stage transitions (Tables 1 and 3). These data seem to further support the hypothesis that invertases play a role

\section{$\underline{\text { Sucrose }}$}

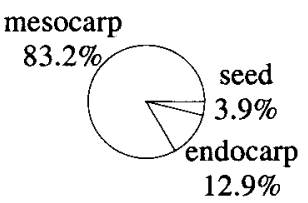

Total Fruit Content $=11.2 \mathrm{mg}$

\section{$\underline{\text { Starch }}$}

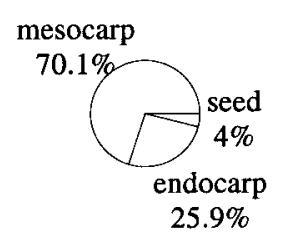

Total Fruit Content $=10.8 \mathrm{mg}$ in plant development (Sturm and Tang, 1999). The decrease in SS activity (assayed in the catabolic direction) in the mesocarp at cell expansion may also contribute to the increase in sucrose: hexose ratios. However, other Researchers found that sucrose phosphate synthase (Hubbard et al., 1991) and an isoform of SS active in the anabolic direction (Moriguchi et al., 1990) may be directly related to sucrose accumulation in peach fruit. Furthermore, the genes for invertase are sugar-modulated (Koch, 1996) and the increase in glucose levels in the mesocarp from cell division to cell expansion may play a role in the repression of the soluble AI gene in peach fruit mesocarp. However, sugar contents per se are not necessarily associated with changes in plant gene expression; rather, carbon flux and hexose phosphorylation are the critical signals (Koch, 1996). Similarly, mesocarp SDH and SOX activities seem to be sugar-regulated, and in particular, to be repressed by sorbitol and/or glucose accumulation in this study. In apple fruit, SDH also appears to be sugar-modulated (Archbold, 1999; Berüter and Studer-Feusi, 1997), but its activity was associated with increases in sorbitol 

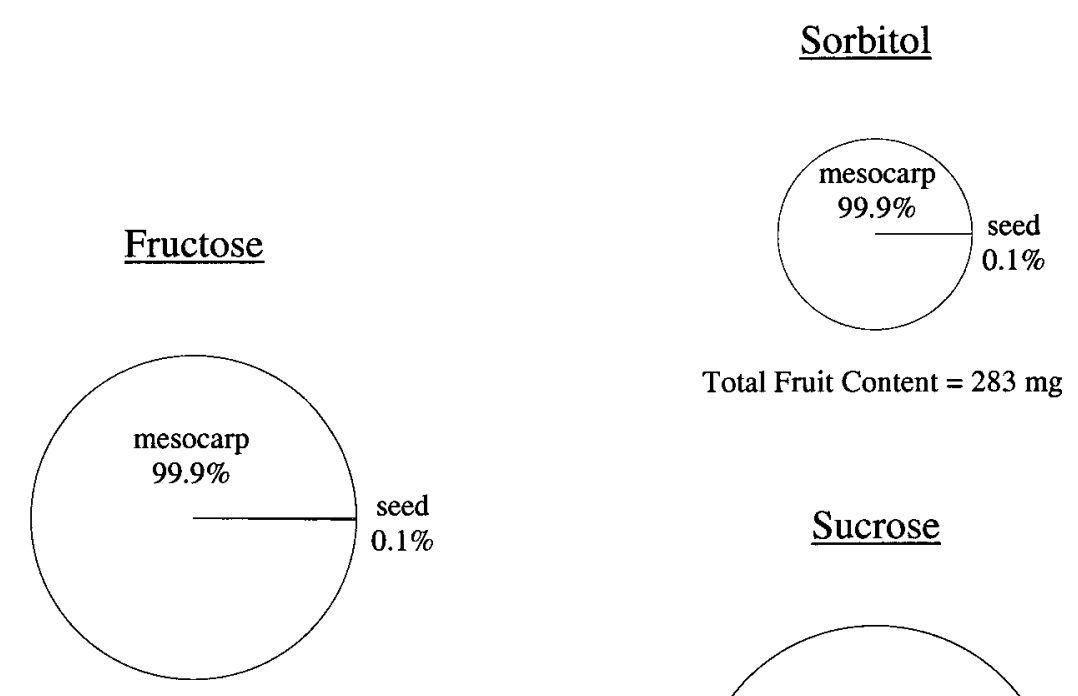

Total Fruit Content $=809 \mathrm{mg}$

\section{$\underline{\text { Glucose }}$}

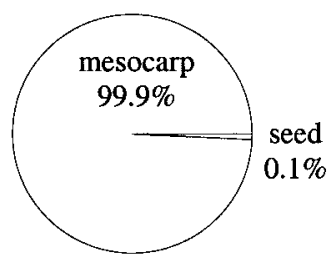

Total Fruit Content $=445 \mathrm{mg}$
Total Fruit Content $=283 \mathrm{mg}$

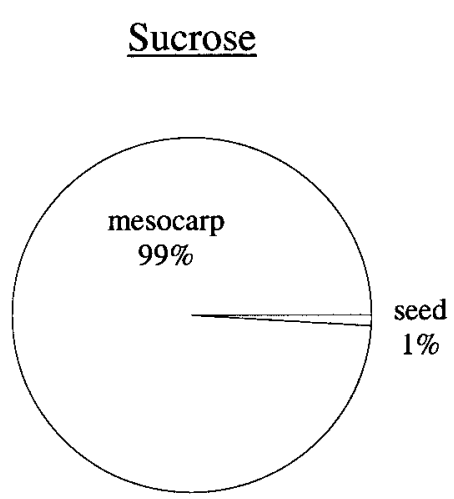

Total Fruit Content $=978 \mathrm{mg}$

\section{$\underline{\text { Starch }}$}

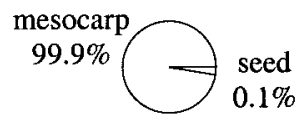

Total Fruit Content $=70 \mathrm{mg}$
At endocarp hardening, starch content is higher in the seed, where SS is the most active enzyme. Also, starch content and SS activity in the mesocarp showed a parallel drop at cell expansion, suggesting a role for SS in cleaving sucrose for use in starch synthesis. SS activity has been associated with starch accumulation in apple fruit (Berüter et al., 1997), in developing pea (Pisum sativum L.) seeds (Déjardin et al., 1997), and in tomato (Lycopersicon esculentum Mill.) fruit (N'tchobo et al., 1999; Wang et al., 1993). However, a definitive role for SS in starch accumulation is unclear because starch content was found to be unaffected in fruit of tomato plants transformed to have reduced SS activity (Chengappa et al., 1999).

Starch is present in the mesocarp at cell division and endocarp hardening stages, but not in the final stage, suggesting that it may represent a transient carbon sink in the peach fruit. In apple fruit, starch is also synthesized temporarily during development, and nearly disappears at fruit maturity. Berüter and Studer-Feusi (1997) found that interrupting carbon import by girdling during the phase of active starch synthesis triggers the decrease of starch levels. They suggested that, under those source-limiting conditions, starch becomes an alternative carbon source for growth and de novo synthesis of sucrose. In our study, disappearance of starch in the mesocarp may have contributed to growth and sucrose accumulation in the cell expansion stage, when fruit growth is likely to be source limited (DeJong and Grossman, 1995).

In conclusion, SorCA and SucCA behave similarly during the last two of the three growth stages of peach fruit. How-
Fig. 3. Partitioning of total fructose, glucose, sorbitol, sucrose, and starch contents among the various tissues of the peach fruit at the endocarp hardening stage. Area of pie charts is proportional to total content per fruit.

and glucose levels (Archbold, 1999). On the contrary, the decrease in SDH and SOX activities after cell division could be responsible for sorbitol accumulation in peach fruit mesocarp.

In peach, loss of SS catabolic activity could be involved in transition to cell expansion stage in the fruit mesocarp. The UDPglucose formed as SS cleaves sucrose is a direct precursor of cellulose (Carpita and Vergara, 1998), which in turn is a component of the cell wall and plays an important role in cell expansion. Cell swelling was indeed observed in roots of Arabidopsis thaliana (L.) Heynh. mutants with reduced cellulose content (Aroli et al., 1998). Hence, the drop in SS activity, and consequent decrease in UDP-glucose availability, may reduce the amount of cellulose incorporated in cell walls, enhancing cell expansion during the final growth stage. ever, when both the size and activity of the sink tissue are taken into account, sorbitol and sucrose catabolism may play different roles at cell division and endocarp hardening. Specifically, at the cell division stage, the mesocarp is the strongest sink for sorbitol, whereas the endocarp is the strongest sink for sucrose. The situation is reversed at endocarp hardening, when sorbitol is more actively catabolized in the seed, and sucrose catabolism is mostly partitioned into the mesocarp. The concerted activity of all enzymes seems responsible for similar sorbitol and sucrose accumulation and partitioning at the final cell expansion stage. Greater partitioning of sorbitol catabolism into the mesocarp in the cell division stage suggests a key role for sorbitol, and perhaps $\mathrm{SDH}$, in determination of final fruit size since cell number in the mesocarp is associated with peach fruit size (Westwood, 1993). SDH activity or the expression/regulation of the SDH gene may represent potential targets in future studies dealing with manipulation of fruit size and yield in peach. 


\section{Sorbitol}

\section{Fructose}

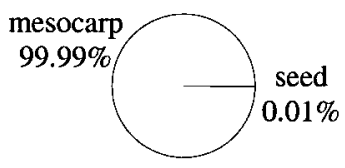

Total Fruit Content $=1157 \mathrm{mg}$

\section{Glucose}

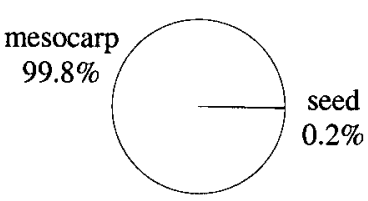

Total Fruit Content $=1670 \mathrm{mg}$

\section{$\underline{\text { Starch }}$}

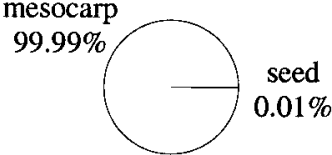

Total Fruit Content $=2666 \mathrm{mg}$

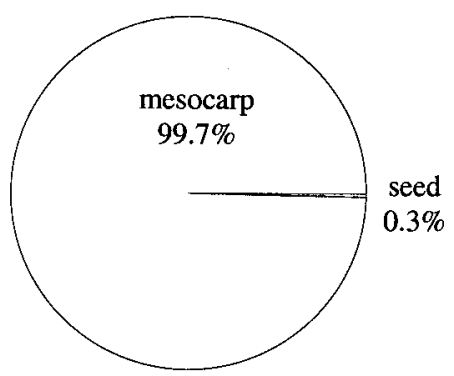

Total Fruit Content $=7012 \mathrm{mg}$

Chengappa, S., M. Guilleroux, W. Phillips, and R. Shields. 1999. Transgenic tomato plants with decreased sucrose synthase are unaltered in starch and sugar accumulation in the fruit. Plant Mol. Biol. 40:213-221.

Déjardin, A., C. Rochat, S. Wuillème, and J.P. Boutin. 1997. Contribution of sucrose synthase, ADP-glucose pyrophosphorylase and starch synthase to starch synthesis in developing pea seeds. Plant Cell Environ. 20:1421-1430.

DeJong, T.M. and Y.L. Grossman. 1995. Quantifying sink and source limitations on dry matter partitioning to fruit growth in peach trees. Physiol. Plant. 95:437-443.

Escobar-Gutiérrez, A.J. and J.P. Gaudillére. 1994. Variability in sorbitol:sucrose ratios in mature leaves of different peach cultivars. J. Amer. Soc. Hort. Sci. 119:321-324.

Farrar, J.F. 1993. Sink strength: What is it and how do we measure it? Introduction. Plant Cell Environ. 16:1015.

Ho, L.C. 1988. Metabolism and compartmentation of imported sugars in sink organs in relation to sink strength. Annu. Rev. Plant Physiol. Plant Mol. Biol. 39:355-378.

Hubbard, N.L., D.M. Pharr, and S.C. Huber. 1991. Sucrose phosphate synthase and other sucrose metabolizing enzymes in fruits of various species. Physiol. Plant. 82:191196.

Koch, K.E. 1996. Carbohydrate-modulated gene expression in plants. Annu. Rev. Plant Physiol. Plant Mol. Biol. 47:509_ 540

Lo Bianco, R., M. Rieger, and S.S. Sung. 1998. A simple, rapid extraction and assay procedure for NAD-dependent sorbitol dehydrogenase (SDH) in peach. J. Amer. Soc. Hort. Sci. 123:1065-1068.

Lo Bianco, R., M. Rieger, and S.S. Sung. 1999a. Carbohydrate metabolism of vegetative and reproductive sinks in the late-maturing peach cultivar 'Encore'. Tree Physiol. 19:103109.

Lo Bianco, R., M. Rieger, and S.S. Sung. 1999b. Activities of sucrose and sorbitol metabolizing enzymes in vegetative sinks of peach and correlation with sink growth rate. J. Amer. Soc. Hort. Sci. 124:381-388.

seed

$100 \%$ 。

Total Fruit Content $=0.13 \mathrm{mg}$

Lo Bianco, R., M. Rieger, and S.S. Sung. 2000. Effect of drought on sorbitol and sucrose metabolism in sinks and sources of peach. Physiol. Plant. 108:71-78.

Loescher, W.H., G.C. Marlow, and R.A. Kennedy. 1982. Sorbitol metabolism and sink-source interconversions in developing apple leaves. Plant Physiol. 70:335-339.

Moriguchi, T., T. Sanada, and S. Yamaki. 1990. Seasonal fluctuations of some enzymes related to sucrose and sorbitol metabolism in peach fruit. J. Amer. Soc. Hort. Sci. 115:278281

Fig. 4. Partitioning of total fructose, glucose, sorbitol, sucrose, and starch contents among the various tissues of the peach fruit at the cell expansion stage. Area of pie charts is proportional to total content per fruit.

\section{Literature Cited}

Amthor, J.S. 1994. Respiration and carbon assimilate use, p. 221-250. In: K.J. Boote, T.R. Sinclair, and J.M. Bennett (eds.). Physiology and determination of crop yield Amer. Soc. Agron. Madison, Wis.

Archbold, D.D. 1999. Carbohydrate availability modifies sorbitol dehydrogenase activity of apple fruit. Physiol. Plant. 105:391-395.

Arioli, T., L. Peng, A.S. Betzner, J. Burn, W. Wittke, W. Herth, C. Camilleri, H. Höfte, J. Plazinski, R. Birch, A. Cork, J. Glover, J. Redmond, and R.E. Williamson. 1998. Molecular analysis of cellulose biosynthesis in Arabidopsis. Science 279:717721.

Berüter J. and M.E. Studer-Feusi. 1997. The effect of girdling on carbohydrate partitioning in the growing apple fruit. J. Plant Physiol. 151:277-285.

Berüter J., M.E. Studer-Feusi, and P. Ruedi. 1997. Sorbitol and sucrose partitioning in the growing apple fruit. J. Plant Physiol. 151:269-276.

Bradford, M.M. 1976. A rapid and sensitive method for the quantitation of microgram quantities of protein using the principle of protein-dye binding. Anal Biochem. 72:248-254.

Carpita, N. and C. Vergara. 1998. A recipe for cellulose. Science 279:672-673.

Chaplin, M.F. 1994. Monosaccharides, p. 1-42. In: M.F. Chaplin and J.F. Kennedy (eds.). Carbohydrate analysis. A practical approach. Oxford Univ. Press, Oxford, U.K.
N'tchobo, H., N. Dali, B. Nguyen-Quoc, C.H. Foyer, and S. Yelle. 1999. Starch synthesis in tomato remains constant throughout fruit development and is dependent on sucrose supply and sucrose synthase activity. J. Expt. Bot. 50:1457-1463.

Sturm, A. and G.-Q. Tang. 1999. The sucrose-cleaving enzymes of plants are crucial for development, growth, and carbon partitioning. Trends Plant Sci. 4:401-403.

Sung, S.S., D.P. Xu, and C.C. Black. 1989. Identification of actively filling sucrose sinks. Plant Physiol. 89:1117-1121.

Vizzotto, G., R. Pinton, Z. Varanini, and G. Costa. 1996. Sucrose accumulation in developing peach fruit. Physiol. Plant. 96:225-230.

Wang, F., A. Sanz, M.L. Brenner, and A. Smith. 1993. Sucrose synthase, starch accumulation, and tomato fruit sink strength. Plant Physiol. 101:321-327.

Warren Wilson, J. 1972. Control of crop processes, p. 7-30. In: A.R. Rees, K.E. Cockshull, D.W. Hand, and R.G. Hurd (eds.). Crop processes in controlled environments. Academic Press, London.

Weber, H., L. Borisjuk, and U. Wobus. 1997. Sugar import and metabolism during seed development. Trends Plant Sci. 2:169-174.

Westwood, M.N. 1993. Fruit growth and thinning, p. 254-274. In: M.N. Westwood (ed.). Temperate-zone pomology. Timber Press, Portland, Ore.

Yamaguchi, H., Y. Kanayama, J. Soejima, and S. Yamaki. 1996. Changes in the amounts of the NAD-dependent sorbitol dehydrogenase and its involvement in the development of apple fruit. J. Amer. Soc. Hort. Sci. 121:848-852.

Yamaki, S. 1980. A sorbitol oxidase that converts sorbitol to glucose in apple leaf. Plant Cell Physiol. 21:591-599.

Yamaki, S. and K. Ishikawa. 1986. Roles of four sorbitol related enzymes and invertase in the seasonal alteration of sugar metabolism in apple tissue. J. Amer. Soc. Hort. Sci. 111:134-137. 